Artikel Penelitian

\title{
PENYELENGGARAAN MAKANAN DI LEMBAGA PEMASYARAKATAN KELAS IIA PALU
}

\author{
Food Service In Prison Class IIA Palu
}

\author{
Oksandi*1 $^{1}$, Nurdin Rahman ${ }^{1}$, Adhar Arifuddin ${ }^{2}$ \\ ${ }^{1 .}$ Bagian Gizi Kesehatan Masyarakat, Fakultas Kesehatan Masyarakat, Universitas Tadulako, Indonesia \\ 2.Program Studi Kesehatan Masyarakat, Fakultas Kesehatan Masyarakat, Universitas Tadulako, Indonesia
}

Diterima: 11 November 2018; Revisi: 12 Desember 2018; Diterbitkan: 31 Desember 2018

Background \& Objective: Quality of the food is oriented towards customer satisfaction that having regard among things like food appearance, taste and variety menu. This study aims to identify factors that associated with satisfaction to the food management for convicted criminal in Prison Class IIA Palu . Material and Methods: This type of research is a cross sectional study. Total population in this study is 422 convicted criminals and the number of samples is 81 convicted criminals by using simple random sampling technique. Data were analyzed by descriptive univariate and bivariate analysis, at the level of trust $95 \%(\mathrm{p}<0.05)$. Results: Respondents assessed the appearance of food that was not good at $24.69 \%$, the taste of food was not good at $14.81 \%$, and the menu variation was not good at $18.51 \%$. This means that the appearance of food, taste of food, and the variety of menus provided include good and satisfaction ratings on the giving of food including satisfaction, namely, 88.88\%. Fisher's Exact test results showed that the appearance of food associated with satisfaction the food service $(\rho=0.006)$, the taste of food associated with satisfaction the food service $(\rho=0.000)$, and variety od menus associated with satisfaction the food service $(\rho=0.009)$. Conclusion: The better quality of the food that provided to the convicted criminals, the more satisfied also for the food service.

Keywords: Food service, Appearance of food, Taste of food, Variety of menus

\section{Abstrak}

Latar Belakang \& Tujuan : Kualitas penyelenggaraan makanan diorientasikan kepada kepuasan konsumen dengan memperhatikan berbagai hal antara lain penampilan makanan, cita rasa dan variasi menu. Penelitian ini bertujuan untuk mengetahui faktor yang berhubungan dengan kepuasan narapidana terhadap penyelenggaraan makanan di Lembaga Pemasyarakatan Kelas IIA Palu. Bahan dan Metode : Jenis penelitian yang digunakan adalah penelitian Cross Sectional. Jumlah populasi yaitu 422 narapidana dan jumlah sampel yaitu 81 narapidana dengan menggunakan teknik Simple Random Sampling. Data dianalisis secara deskriptif yaitu analisis univariat dan bivariat, pada taraf kepercayaan 95\% ( $<<0,05)$. Hasil : Responden menilai penampilan makanan yang kurang baik yaitu 24,69\%, cita rasa makanan yang kurang baik yaitu $14,81 \%$, dan variasi menu yang kurang baik yaitu $18,51 \%$. Hal ini berarti bahwa penampilan makanan, citarasa makanan, dan variasi menu yang disediakan termasuk baik dan penilaian kepuasan terhadap penyelenggaraan makanan termasuk puas yaitu, $88,88 \%$. Penelitian menunjukkan bahwa penampilan makanan berhubungan dengan kepuasan penyelenggaraan makanan $(\rho=0,006)$, cita rasa makanan berhubungan dengan kepuasan penyelenggaraan makanan $(\rho=0,000)$, dan variasi menu berhubungan dengan kepuasan penyelenggaraan makanan $(\rho=0,009)$. Kesimpulan : Semakin baik mutu makanan yang disediakan untuk narapidana, maka semakin puas pula terhadap penyelenggaraan makanan.

Kata Kunci: Penyelenggaraan makanan, penampilan makanan, citarasa makanan, dan variasi menu

*Korespondensi: Telp: +62 822-9205-6162, Email : bloomandi10@gmail.com

\section{PENDAHULUAN}

Upaya agar kebutuhan zat gizi seseorang dapat diperoleh secara optimal adalah dengan diadakannya penyelenggaraan makanan yang dikelola dengan menerapkan disiplin-disiplin ilmu seperti ilmu gizi, mana- jemen, dietetika, serta dilakukan dengan menerapkan prinsip efisiensi dan efektivitas karena tujuan dari penyelenggaraan makanan adalah menghasilkan makanan yang berkualitas baik dan sesuai kebutuhan (Mukrie,1990) 
Kualitas penyelenggaraan makan diorientasikan kepada kepuasan konsumen dengan memperhatikan berbagai hal antara lain penampilan makanan, cita rasa makanan, kebutuhan alat, ketepatan waktu dalam menghidangkan makanan serta sikap dan perilaku petugas dalam menghidangkan makanan yang secara langsung maupun tidak langsung bisa mempengaruhi selera makan konsumen (Suryawati, 2004).

Penyelenggaraan makanan di Lembaga Pemasyarakatan Kelas IIA Palu dilaksanakan oleh para warga binaan, dimana keterampilan memasak diperoleh dari sesama narapidana yang sebelumnya bertugas sebagai pengelola makanan. Menurut persyaratan pelaksanaan makanan institusi, pengelolaan makanan harus dilaksanakan oleh petugas yang berpengalaman dan mempunyai keahlian dibidang masak-memasak, sehingga mutu dan cita rasa makanan terjamin. Namun petugas pengelola makanan dilakukan oleh narapidana dengan kemampuan memasak alamiah, ini menyebabkan makanan yang dihasilkan sangat sederhana dengan mutu dan cita rasa makanan yang kurang terjamin. Tentu saja hal ini menyebabkan para narapidana kurang berselera dengan makanan yang sudah dimasak.

Hal diatas juga didukung dengan hasil wawancara yang dilakukan terhadap 10 narapidana mengenai menu makanan yang disediakan, 7 narapidana mengatakan bosan terhadap menu makanan yang disediakan. Kebosanan terhadap makanan yang disediakan karena menu yang disediakan sederhana dan rasa makanan yang kurang enak. Kebosanan terhadap makanan dapat berpengaruh terhadap daya terima makanan narapidana dan mempengaruhi asupan zat gizi para narapidana (Marwato,2010).

Berdasarkan latar belakang yang telah diuraikan, maka peneliti tertarik untuk meneliti mengenai faktor yang berhubungan dengan kepuasan narapidana terhadap penyelenggaraan makanan di Lembaga Pemayarakatan Kelas IIA Palu.

\section{BAHAN DAN METODE}

\subsection{Jenis Penelitian}

Jenis penelitian ini menggunakan metode survey analitik dengan pendekatan cross sectional, yakni untuk melihat hubungan antara penampilan makanan, citarasa makanan dan variasi menu dengan kepuasan narapidana terhadap penyelenggaraan makanan di Lembaga Pemasyarakatan Kelas IIA secara simultan (bersamaan)

\subsection{Lokasi dan waktu penelitian}

Lokasi penelitian dilakukan di Lembaga Pemasyarakatan Kelas IIA Palu, dilakukan pada bulan September - Oktober 2016

\subsection{Populasi dan sampel}

Populasi pada penelitian ini adalah narapidana di Lembaga Pemayarakatan Kelas IIA Palu sebanyak 422 orang dan jumlah sampel dalam penelitian ini sebanyak 81 responden dengan menggunakan teknik Simple Random Sampling.

\subsection{Analisis Data}

Analisis univariat dan bivariat, pada taraf kepercayaan $95 \%(\mathrm{p}<0,05)$

\section{HASIL}

Tabel 1 menunjukkan bahwa berdasarkan hasil analisis menggunakan uji Fisher's Exact yang dilakukan terhadap penampilan makanan, citarasa makanan dan variasi menu dengan kepuasan penyelenggaraan makanan didapatkan hasil yaitu penampilan makanan berhubungan dengan kepuasan penyelenggaraan makanan dengan nilai $\rho=0,006$, citarasa makanan berhubungan dengan kepuasan penyelenggaraan makanan dengan nilai $\rho=0,000$ dan variasi menu berhubungan dengan kepuasan penyelenggaraan makanan dengan nilai $\rho=0,009$

\section{PEMBAHASAN}

\section{Penampilan Makanan}

Berdasarkan hasil analisis menggunakan uji Fisher's Exact yang dilakukan terhadap penampilan makanan dengan kepuasan narapidana terhadap penyelenggaraan makanan di Lembaga Pemasyarakatan Kelas IIA Palu, didapatkan hasil nilai $\rho=0,006$ sehingga $\rho<0,05$ maka Ho pada penelitian ini ditolak, artinya bahwa ada hubungan penampilan makanan dengan kepuasan narapidana terhadap penyelenggaraan makanan di Lembaga Pemasyarakatan Kelas IIA Palu.

Penampilan makanan sangat mempengaruhi penerimaan makanan. Hal ini karena variasi warna yang baik akan meningkatkan selera makan sehinggga meningkatkan penerimaan makanan. Selain aspek warna, aspek besar porsi dan bentuk makanan sangat mempengaruhi selera makan. Apabila makanan tersebut terlalu besar atau terlalu kecil akan sangat mempengaruhi terhadap penerimaan makanan. Sehingga besar porsi yang sesuai akan berpengaruh terhadap penerimaan makanan. Begitu juga dengan bentuk makanan yang disajikan, semakin beragam bentuk dan potongan makanan akan semakin menambah selera makan. Selera makan yang baik menunjukkan bahwa konsumen puas terhadap pelayanan makanan yang disediakan oleh pihak penyelenggara (Wood, 1988).

Penelitian ini sejalan dengan penelitian sebelumnya pada pasien di rumah sakit militer Turki yang menemukan adanya hubungan antara penampilan makanan dengan kepuasan pasien terhadap pelayanan makanan yang disajikan rumah sakit ( $\rho$ value $0,014<$ $0,05)$ (Sahin,2006). Warna makanan yang menarik pada waktu penyajian makanan atau kombinasi warna yang menarik antara lauk hewani, lauk nabati, dan sayuran akan meningkatkan kepuasan (Asrina, 2012).

\section{Citarasa Makanan}

Berdasarkan hasil analisis menggunakan uji Fisher's Exact yang dilakukan terhadap citarasa makanan dengan kepuasan narapidana terhadap penyelenggaraan makanan di Lembaga Pemasyarakatan Kelas IIA Palu, didapatkan hasil nilai $\rho=0,000$ sehingga $\rho<0,05$ maka Ho pada penelitian ini ditolak, artinya bahwa ada hubungan citarasa makanan dengan kepuasan narapidana terhadap penyelenggaraan makanan di Lembaga Pemasyarakatan Kelas IIA Palu.

Penilaian terhadap citarasa makanan dipengaruhi oleh indera penciuman, indera pengecapan dan indera penglihatan. Makanan yang memiliki citarasa yang baik adalah makanan yang penampilannya menarik dan memiliki rasa yang baik juga (Santoso, 2004). Rasa makanan dapat mempengaruhi selera makan konsumen. Selera makan ini akan berpengaruh terhadap daya terima makanan konsumen. Jadi, apabila selera makan baik, daya terima makanpun menjadi baik. Juga sebaliknya, apabila selera makan kurang 
baik, maka daya terimapun menjadi kurang baik. Daya terima makan menunjukkan kepuasan terhadap makanan yang disediakan. Jadi, apabila daya terima makan baik, maka konsumen merasa puas terhadap pelayanan makan. Juga sebaliknya, apabila daya terima makan kurang baik, maka konsumen merasa kurang puas terhadap pelayanan makan (Khan, 1987). Tingkat pelayanan yang pasti dan memuaskan akan meningkatkan kepuasan konsumen (Yoestini, 2007).

Hasil penelitian ini sejalan dengan dengan penelitian sebelumnya, yang menyatakan bahwa citarasa makanan berhubungan dengan kepuasan pasien diruang penyakit dalam ruang bersalin RSUD Mandau Duri dengan nilai $\rho$ value $0,000<0,05$ (Ernalia, 2014). Hal yang sama juga didapatkan penelitian lainnya yang menyatakan penilaian rasa makanan yang kurang mempengaruhi kepuasan siswa terhadap makanan yang disediakan pihak penyelenggara makanan, dimana mayoritas siswa menunjukkan tidak puas (Ode, 2013).

\section{Variasi Menu}

Berdasarkan hasil analisis menggunakan uji Fisher's Exact yang dilakukan terhadap variasi menu dengan kepuasan narapidana terhadap penyelenggaraan makanan di Lembaga Pemasyarakatan Kelas IIA Palu, didapatkan hasil nilai $\rho=0,009$ sehingga $\rho<$ 0,05 maka Ho pada penelitian ini ditolak, artinya bahwa ada hubungan variasi menu dengan kepuasan narapidana terhadap penyelenggaraan makanan di Lembaga Pemasyarakatan Kelas IIA Palu.

Variasi menu atau hidangan merupakan salah satu faktor yang menentukan tingkat penerimaan makanan konsumen. Variasi menu akan merangsang selera makan, makanan bervariasi akan menambah gairah untuk makan, akibatnya makanan yang disajikan akan dapat dihabiskan (Moehyi,1992).

Hasil penelitian ini sejalan dengan dengan penelitian sebelumnya, yang menyatakan bahwa variasi menu berhubungan dengan kepuasan konsumen yaitu dengan $\rho$ value 0,001<0,05 (Purba, 2013). Penelitian ini juga sejalan dengan penelitian lainnya yang menyatakan variasi makanan akan meningkatkan kepuasan pasien terhadap pelayanan makanan rumah sakit (Chung, 2007).

\section{E. KESIMPULAN}

Penampilan makanan, citarasa makanan dan variasi menu berhubungan dengan kepuasan narapidana terhadap penyelenggaraan makanan. Adapun saran yang dapat diberikan pada penelitian ini yaitu diharapkan kepada pihak penyelenggara pelayanan makanan di Lembaga Pemasyarakatan Kelas IIA Palu tetap mempertahankan bahkan lebih meningkatkan pelayanan makanan yang disediakan dengan cara melakukan pelatihan kepada pengelola makanan tentang cara pengolahan makanan yang baik dan memperhatikan hygiene sanitasi pengolahan makanan, sehingga diharapkan asupan makan narapidana terpenuhi melalui makanan yang baik.

\section{F. DAFTAR PUSTAKA}

Asrina, 2012, 'Gambaran Tingkat Kepuasan Siswa Terhadap Mutu Hidangan di Asrama SMA Negeri 2 Tinggimoncong (Sekolah Andalan Sulsel) Kabupaten Gowa Provinsi Sulsel', Skripsi, Universitas Hasanuddin, Makassar.

Chung, S, H, Yeom, H, S, \& Sohn, C, M, 2007, The Improvement of Hospital Food Service in Quality and Costumer Satisfication by Using 6-sigma Strategy, Journal of Korean Diet Assoc, vol. 13, no. 4, page 331-344.

Ernalia, Y, 2014, Faktor-Faktor yang Berhubungan dengan Kepuasan Pasien Di Ruang Penyakit Dalam dan Ruang Bersalin Terhadap Pelayanan Makanan Pasien Di RSUD Mandau Duri, Jurnal Gizi, vol. 3, no. 1, hal 36-47.

Khan, Mahmood, 1987, Food Service Operation, An Avi Book, New York.

Marwati, 2010, Keamanan Pangan dan Penyelenggaraan Makanan, [http://staff.uny.ac.id/sites/ default/files/Keamanan\%20Pangan.pdf].

Moehyi, S, 1992, Penyelenggaraan Makanan Institusi dan Jasa Boga, Bhratara, Jakarta.

\begin{tabular}{|c|c|c|c|c|c|c|}
\hline & \multicolumn{4}{|c|}{ Kepuasan Penyelenggaraan Makanan } & \multirow{3}{*}{ Total } & \multirow{3}{*}{$\mathbf{P}$} \\
\hline & \multicolumn{2}{|c|}{ Kurang Puas } & \multicolumn{2}{|c|}{ Puas } & & \\
\hline & $\mathrm{n}$ & $\%$ & $\mathrm{n}$ & $\%$ & & \\
\hline \multicolumn{7}{|c|}{ Penampilan Makanan } \\
\hline Kurang Baik & 6 & 30,0 & 14 & 70,0 & 20 & \multirow{2}{*}{0,006} \\
\hline Baik & 3 & 4,9 & 58 & 95,1 & 61 & \\
\hline \multicolumn{7}{|c|}{ Citarasa Makanan } \\
\hline Kurang Baik & 6 & 50,0 & 6 & 50,0 & 12 & \\
\hline Baik & 3 & 4,3 & 66 & 95,7 & 69 & 0,000 \\
\hline \multicolumn{7}{|l|}{ Variasi Menu } \\
\hline Kurang Baik & 5 & 33,3 & 10 & 66,7 & 15 & 0,009 \\
\hline Baik & 4 & 6,1 & 62 & 93,9 & 66 & \\
\hline
\end{tabular}

Tabel 1 Hubungan Penampilan Makanan, Citarasa Makanan dan Variasi Menu Dengan Kepuasan Narapidana di Lembaga Pemayarakatan Kelas IIA Palu 
Mukrie, N, A, Ginting, Iskari, N, Augustina, H, \& Ningsi, B, 1990, Manajemen Pelayanan Gizi Institusi Dasar, Akademi Gizi, Depkes RI, Jakarta.

Ode, W, A, Djunaidi, M, D, \& Yustini, 2013, Gambaran Tingkat Kepuasan, Siswa terhadap Mutu Hidangan pada Penyelenggaraan Makanan di Sekolah Polisi Negara (SPN) Batua Polda Sulses Tahun 2013, Jurnal Media Kesehatan Masyarakat Indonesia, vol. 3 , no. 2.

Purba, R, B, Grace, K, \& Alfa C, L, 2013, 'FaktorFaktor yang Berhubungan dengan Tingkat Kepuasan Pasien pada Penyelenggaraan di BLU IRINA C Rumah Sakit Umum Pusat Prof. DR. R.D Kandau Manado', Skripsi, Fakultas Kesehatan Masyarakat Sam Ratulangi Manado, Manado.

Sahin, B, Cesim, D, Abdul, K, T, \& Yusuf C, 2006, Factors Affecting Satisfaction Level with the Food Services in a Military Hospital. Journal Medical System, vol 30, no. 5, page 381-387.

Santoso, S, \& Anne, L, R, 2004. Kesehatan dan Gizi, PT. Rineka Cipta, Jakarta.

Suryawati, C, 2004, Kepuasan Pasien Rumah Sakit (Tinajauan Teoritis dan Penerapannya Pada Penelitian, Jurnal Manajemen Pelayanan Kesehatan, vol. 7, no. 4, hal. 189-194.

Wood, L, \& West, B, B, 1988, Foodservice In Institutions Sixth Edition, Macmilian Publishing Company, New York.

Yoestini, Bayu, H, M, Rini, N, \& Mustofa, K, 2007, Analisis Pengaruh Kualitas Produk dan Kualitas Layanan terhadap Kepuasan Konsumen (Studi Kasus pada Perumahan Puri Mediterania Semarang), Jurnal Studi Manajemen dan Organisasi, vol. 4, no. 2, hal. 92 . 